\title{
ONCE UPON A COUNTRY. A PALESTINIAN LIFE
}

\author{
Sari Nusseibeh (with Anthony David) (London: Halban, 2009 (2 \\ edn) 534 pp ISBN 9781905559145
}

\author{
Conor Gearty*
}

This is the autobiography of an academic whose enthralling story is about far more than merely himself. Sari Nusseibeh is a philosopher who is President of Al-Quds University in Jerusalem. His family have been in that city for well over a thousand years - there are stories here about the (female) ancestor who was a first follower of the Prophet and the $7^{\text {th }}$ century relative who was installed by Caliph Omar as the first Moslem high judge of Jerusalem and given custody of the key to the Church of the Holy Sepulchre. This key has mattered a lot to the Nusseibehs; give or take the occasional Crusade, they have held it through the centuries, the Moslem doorkeeper to the fighting Christians on the site of Christ's crucifixion. Nusseibeh is hilarious on this as he is on so much else in the first half of the book. Dominating these early pages is his extraordinary father: lawyer; tennis player of renown; Cambridge graduate; fighter for the Palestinians (he was shot in the 1948 war and lost a leg); and then (during the Jordanian hegemony that followed that national catastrophe) governor of Jerusalem, Jordan's Ministry of Defence and her Ambassador to the United Kingdom. His funeral in 1986 'turned into the largest political demonstration in Jerusalem since the occupation' - the 'crowd like water from a fire hose aimed into a maze'.

By the time of his father's death, Sari Nusseibeh was himself a public figure, having become heavily involved in Palestinian affairs from his academic base in Bir Zeit after Oxford and a Harvard PhD (where he worked on his dissertation on Avicenna 'the way an artist chisels away at a piece of marble'). Married to Lucy Austin (who comes across in this book as dazzlingly indefatigable on both her own and her husband's behalf) and with a young family, Nusseibeh's life is tied from adulthood to the situation his history had thrown him into. He is deeply involved in the first Intifada. Then he is Arafat's man in Jerusalem, reluctantly trying to do what is right for an old man whose words of support and guidance are jumbled and selfcontradictory. A peace plan pops up, Nusseibeh is behind it. Israeli's Mossad

\footnotetext{
* Professor of Human Rights Law LSE.
} 


\section{BOOK REVIEW}

boss recants his brutality in retirement and extending an olive branch to the Palestinians finds Sari Nusseibeh willing to grasp it. The Israeli wall arrives in the middle of Al-Quds - but Nusseibeh manages to divert it, thus saving his university. All the time, he is fighting with words, talking, arguing, thinking it will be different next time round. His passion for engagement makes enemies on both sides but his spirit is undimmed. Only in the preface to this second edition, recounting a recent story of the horrible humiliation of his mother by Israeli airport security, does the avuncular mask briefly slip and terrible despair is glimpsed for a moment, tearing this trusting soul to shreds.

The book is not only a compelling political tale but also (perhaps even mainly) it is a moving love story. Nusseibeh is a man of many loves. His family, of course - a constant theme in this book. Fortunately he loves himself as well - we read of the many crowds swayed by his articulacy, the power of his ideas to achieve change, his successes as a university president, his ability to stand up to Arafat while others creep around him with practised servility. None of this is pompous - already in love with Nusseibeh, the reader greets it with delight: 'Thank God he has himself to rely on'. For the love affair with his people is a grim read. I have not read a better account of the whole tragic imbroglio that is $20^{\text {th }}$ century Palestine. It is all here: the Arab revolt of the 1930s; the Nakba (catastrophe) of 1948 when the state of Palestine - designated by the United Nations - was (to describe brutality with euphemistic mildness) swallowed up by its neighbours; the 1967 war and the long occupation that has followed, punctuated by occasional vicious escalations in the killing and cruel suggestions of peace which are never meant to mean anything at all. The grimness comes in manageable chunks when interspersed with family history as it is here, and the spirit of the author keeps the reader going - there is always a joke or a piece of mock selfdeprecation or an acute aside around the corner, lightening the mood after some gruesome but necessary tale.

Sari Nusseibeh loves the Israeli Jews too. They are just like the Palestinians, he feels, with a decent peace as necessary to them as to the people they oppress. Many Israeli Jews agree with him - and not just the Peace Now brigade but the likes of the old Mossad guy as well. This is why he has so often himself been subject to state attacks, sometimes physical (arrest and detention) but more often in the form of surveillance, harassment and verbal abuse. In the official Israeli version of Palestine Sari Nusseibeh Rugby, Oxford, Harvard, cultured, peace-loving, courageous, accommodating and literate - should not exist. Much easier to see 'the Arabs' through the prism of suicide bombs, international terrorism and Hamas (which through its keen support for Sheikh Yassin the Israelis largely created). This book is at its saddest when a bewildered Nusseibeh recounts the latest example of the deliberate murder by the Israelis of a Palestinian leader with enough status, 
intelligence and desire to make peace; 'Don't they want peace?', he asks, his narrative having already made clear what the answer is.

The book ends with the dreadful wall, 'the perfect crime' which is disfiguring Palestine, possibly for a hundred years. It came about because of an 'unassuming geographer at Haifa University who had made a reputation for himself as a prophet of the Arab demographic time bomb'. To Professor Arnon Sofer, electric fences were the answer. Ariel Sharon heard his paper at a conference and was naturally enthusiastic. Sari Nusseibeh has opposed the academic boycott of Israel, and from this great conciliator you would expect nothing less. But in many ways this wonderful book stands as a monument to the futility of engagement with a powerful enemy which has no desire for a just peace, nor any internal or external pressure on it to work towards one. Violence is wrong and doesn't work. Engagement is right and doesn't work. People say a boycott is out of the question. What next, surrender? 